Elsevier

GENE 1198

\title{
Isolation of a human tissue-type plasminogen-activator genomic DNA clone and its expression in mouse $\mathbf{L}$ cells
}

(Recombinant DNA; cosmid vector; bacteriophage $\lambda$; fibrinolysis; Bowes melanoma)

\author{
M.J. Browne, A.W.R. Tyrrell, C.G. Chapman, J.E. Carey, D.M. Glover a, F.G. Grosveld ${ }^{\text {b }}$, I. Dodd and J.H. \\ Robinson
}

Beecham Pharmaceuticals Research Division, Biosciences Research Centre, Great Burgh, Yew Tree Bottom Road, Epsom, Surrey, KT18 5XQ, Tel. 0737353344 ; $^{a}$ Biochemistry Department, Imperial College, London, SW7 2AZ, Tel. 015895111 , and ${ }^{b}$ Laboratory of Gene Structure and Expression, N.I.M.R., Mill Hill, London, NW7 1AA (U.K.) Tel. 019593666

(Received August 23rd, 1984)

(Revision received and accepted October 23rd, 1984)

\section{SUMMARY}

We have isolated a cDNA clone corresponding to a substantial portion of the human tissue-type plasminogen activator (t-PA) protein. It encodes almost all of the protein $B$ chain and part of the $3^{\prime}$ untranslated region. We have used this clone to screen bacteriophage $\lambda$ and cosmid libraries of human genomic DNA. Several related genomic clones were isolated. One of these, a cosmid clone, carried approx. $40 \mathrm{~kb}$ of human DNA. Mapping experiments indicate that the region containing the protein-coding exons is approx. $20 \mathrm{~kb}$ in length. The cosmid, containing the t-PA gene and the aminoglycosyl-3'-phosphotransferase dominant-selection marker, was introduced into mouse L cells. Approximately half of the transformants were shown to produce human t-PA. We demonstrated that the fibrinolytic t-PA activity could be specifically quenched by anti-t-PA antibody and that the recombinant t-PA was of similar size (by SDS-polyacrylamide gel electrophoresis) to the t-PA produced by the human Bowes melanoma cell line. Our results suggest that the cosmid clone carries the whole t-PA coding region together with the regulatory elements necessary for its expression.

\section{INTRODUCTION}

Plasminogen activators appear to play an important role in the fibrinolytic system. These enzymes are capable of converting inactive plasminogen to its catalytically active form, plasmin, which degrades

\footnotetext{
Abbreviations: bp, base pair(s); EtBr, ethidium bromide; HPLC, high-performance liquid chromatography; kb, $1000 \mathrm{bp}$; SDS, sodium dodecyl sulphate; SSC, $0.15 \mathrm{M} \mathrm{NaCl}, 0.015 \mathrm{M}$ $\mathrm{Na}_{3} \cdot$ citrate, pH 7-8; t-PA, human tissue-type plasminogen activator; u-PA, human urokinase-type plasminogen activator.
}

the fibrin network associated with blood clots. There are two major types of human plasminogen activator, namely urokinase-type plasminogen activator (u-PA) and tissue-type plasminogen activator (t-PA). These proteins are immunologically distinct, differ in $M_{\mathrm{r}}$ and are encoded by different genes (Heyneker et al., 1982; Pennica et al., 1983). Particular attention has been drawn to the clinical use of t-PA since recent studies indicate that administration of t-PA may provide therapeutic benefit in iliofemoral thrombosis (Weimar et al., 1981) and in thrombolysis of myocardial infarctions (Van de Werf et al., 1984). 
The current method of production of t-PA from the human Bowes melanoma cell line is, however, unlikely to provide sufficient t-PA for future clinical needs (Rijken and Collen, 1981; Van de Werf et al., 1984). As a consequence, a number of laboratories are attempting to produce t-PA by means of recombinant DNA technology. Thus cDNA clones have been obtained (Pennica et al., 1983; Edlund et al., 1983) and the t-PA cDNA expressed in Escherichia coli (Pennica et al., 1983). We decided to isolate the genomic DNA for t-PA in order to provide a basis for a better understanding of the t-PA molecule. We were also interested in the feasibility of expressing the t-PA gene in mammalian cell culture since t-PA synthesised in E. coli is not glycosylated (Pennica et al., 1983). We took advantage of recent advances in cosmid cloning technology which, combined with new dominant selection markers, facilitate the isolation of genomic DNA clones spanning even relatively large genes and the direct expression of such genes in eukaryotic systems (Grosveld ct al., 1982).

\section{MATERIALS AND METHODS}

\section{(a) Enzymes and special materials}

Restriction endonucleases, T4 DNA ligase and polynucleotide kinase were obtained from Bethesda Laboratories (U.K.) Ltd. Nitrocellulose filters (BA 85) were from Schleicher \& Schüll GmbH, Dassel, W. Germany, and GeneScreen ${ }^{\mathrm{TM}}$ was from New England Nuclear, Boston, MA, U.S.A. Urokinase was from Leo Laboratories Ltd., U.K. Human fibrinogen was from Flow Laboratories, Irvinc, U.K. Radioisotopically labelled compounds and nicktranslation kits were from Amersham International plc, U.K. Fuji-RX film was from Fujimex Ltd., Dorcan, U.K. Antibiotic G418 sulphate was from Gibco Europe Ltd., Paisley, U.K.

\section{(b) Purification of messenger RNA}

Total RNA was isolated from Bowes melanoma cells (Rijken and Collen, 1981) by phenol extraction (Scott et al., 1983) and mRNA was purified by single cycles of poly(U)-Sepharose or oligo(dT)-cellulose chromatography (Legon et al., 1982).

\section{(c) Identification of a t-PA cDNA clone}

$10 \mu \mathrm{g}$ of total mRNA was used to prepare a cDNA library of approx. 50000 recombinants. The cDNA was inserted into the $\mathrm{pCD} 5$ plasmid vector by $\mathrm{dC}$ : dG tailing and transformed into $E$. coli $\mathrm{DH} 1$ cells as described by Scott et al. (1983). The library was propagated on nitrocellulose filters and replicas were prepared for screening (Hanahan and Meselson, 1980). Hybridising colonies were detected by autoradiography.

\section{(d) Oligonucleotide probes}

Oligonucleotide probes were synthesised from dimer building blocks by the solid phase phosphotriester method (Gait et al., 1982) and purified by preparative ion-exchange HPLC. Probes were endlabelled to a specific activity of $5 \times 10^{7} \mathrm{dpm} / \mu \mathrm{g}$ with $\left[\gamma^{32} \mathrm{P}\right]$ ATP as described by Maxam and Gilbert (1980). Hybridisations were performed, at $37^{\circ} \mathrm{C}$ for $16 \mathrm{~h}$, essentially as described by Dalbadie-MacFarland et al. (1982), except that $0.1 \%$ SDS was substituted for NP40 in the hybridisation buffer. Filters were then washed for $4 \times 15 \mathrm{~min}$ in $6 \times \mathrm{SSC}$ containing $0.1 \%$ SDS at $45^{\circ} \mathrm{C}$.

\section{(e) Identification of genomic t-PA clones}

An amplified $\lambda$ Charon $4 \mathrm{~A}$ bacteriophage human DNA library, kindly provided by T. Maniatis (Lawn et al., 1978), was propagated in $\boldsymbol{E}$. coli LE392, and nitrocellulose copies were prepared for screening (Benton and Davis, 1977). A further human DNA library of $5 \times 10^{5}$ independent recombinants was prepared in the pTCF cosmid vector and nitrocellulose replicas were prepared for screening as described previously (Grosveld et al., 1982). Genomic libraries were screened using the appropriate nick-translated probe as follows. Nitrocellulose filters were prehybridised in a solution of $3 \times \mathrm{SSC}$, $0.1 \%$ SDS, $50 \mu \mathrm{g}$ denatured sonicated salmon sperm DNA, $0.2 \%$ Ficoll, $0.2 \%$ bovine serum albu$\min , 0.2 \%$ polyvinylpyrrolidone for $2 \mathrm{~h}$ at $65^{\circ} \mathrm{C}$. Hybridisation was for $16 \mathrm{~h}$ at $65^{\circ} \mathrm{C}$ in the same solution. Filters were washed for $6 \times 30 \mathrm{~min}$ at $65^{\circ} \mathrm{C}$ in $0.1 \times \mathrm{SSC}$ containing $0.1 \% \mathrm{SDS}$, followed by $2 \times 30$-min washes at room temperature in $3 \mathrm{mM}$ Tris base. 


\section{(f) Northern and Southern blotting of nucleic acids}

mRNA was fractionated by electrophoresis in a $1 \%$ agarose gel containing formaldehyde and then transferred to GeneScreen (Thomas, 1980). Human 18 and $28 \mathrm{~S}$ ribosomal RNAs, stained with $\mathrm{EtBr}$, were used as size markers. DNA was fractionated on agarose gels and blotted onto nitrocellulose as described by Southern (1975).

\section{(g) DNA sequencing}

The sequences of the oligonucleotide probes were verified by the method of Maxam and Gilbert (1980). Sequencing of cloned DNA was performed using the chain-termination method (Smith, 1980; Messing et al., 1981).

\section{(h) Transformation of mouse $\mathbf{L}$ cells}

Transformation of mouse $L$ cells using cosmid DNA was carried out essentially as described previously (Grosveld et al., 1982). $10 \mu \mathrm{g}$ of cosmid DNA (without carrier) was precipitated onto approx. $10^{6}$ cells per $90-\mathrm{mm}$ dish. Transformants were selected using $400 \mu \mathrm{g} / \mathrm{ml} \mathrm{G} 418$ sulphate. Colonies of 1 to $2 \mathrm{~mm}$ diameter were clearly visible 12 to 14 days after transformation and were individually harvested for propagation and assay of t-PA production.

\section{(i) Characterisation of t-PA}

Cell cultures were washed twice with serum-free medium and were incubated in serum-free medium for $48 \mathrm{~h}$ to harvest secreted t-PA. The medium was collected, Tween- 80 added to $0.01 \%(\mathrm{w} / \mathrm{v})$ and activity measured on fibrin plates (Granelli-Piperno and Reich, 1978). The $M_{\mathrm{r}}$ of plasminogen activators was determined by electrophoresis on $8 \%$ SDSpolyacrylamide gels using a $4 \%$ stacking gel (Laemmli, 1970) and the fibrinolytically active species identified by fibrin zymography (GranelliPiperno and Reich, 1978). Where appropriate t-PA was purified by continuous chromatography using zinc chelate (Rijken and Collen, 1981) and lysine Sepharose.

Antibodies to t-PA (from Bowes melanoma cells) or $\mathrm{U}-\mathrm{PA}$ were raised in rabbits and the IgG fraction purified according to Hjelm et al. (1972).

\section{RESULTS AND DISCUSSION}

\section{(a) Identification and isolation of a t-PA cDNA clone}

We constructed a nonadecameric oligonucleotide (probe 1) of sequence $5^{\prime}$-d(CCTGGTCACGGTCGCATGT)-3' which we reasoned would provide a unique probe for t-PA mRNA and its corresponding cDNA. This oligonucleotide sequence spans the boundary between the t-PA B chain coding region and the $3^{\prime}$ untranslated region of the mRNA (Pennica et al., 1983). The selectivity of the oligonucleotide was assessed by probing a Northern blot of Bowes melanoma cell mRNA. Under appropriate conditions we observed a single hybridising band which migrated between the $18 \mathrm{~S}$ and $28 \mathrm{~S}$ ribosomal RNA markers. This result is consistent with previous estimates for the size of the t-PA mRNA (Pennica et al., 1983; Edlund et al., 1983). A cDNA library of approx. 50000 recombinants was prepared from Bowes melanoma cell mRNA and was probed under the same conditions as the Northern blot. A single clone (pTR5) was isolated and sequence analysis confirmed that it encoded part of the t-PA protein. The clone extends from nucleotide 1084 to nucleotide 2109 of the full cDNA molecule (Pennica et al., 1983) and corresponds to the majority of the t-PA B chain (lacking only $69 \mathrm{bp}$ at the $5^{\prime}$ end) plus a large segment of the $3^{\prime}$ untranslated region.

\section{(b) Identification and isolation of t-PA genomic DNA clones}

The plasmid pTR5 was digested with ClaI and Sall to release the t-PA cDNA (Legon et al., 1982) which was then separated from vector DNA by agarose gel electrophoresis (Maniatis et al., 1982) and nick-translated to a specific activity of 1 to $3 \times 10^{8} \mathrm{dpm} / \mu \mathrm{g}$ (Rigby et al., 1977).

$1.3 \times 10^{6}$ recombinants from the bacteriophage library were screened with the t-PA cDNA probe as described in MATERIALS AND METHODS, section e, and seven recombinants were isolated. Restriction enzyme analysis of these cloned genes revealed that they were all very similar (not shown).

$8 \times 10^{5}$ colonies from the cosmid library, which originally contained $5 \times 10^{5}$ colonies, were also screened with the t-PA cDNA probe and two colonies were isolated. Restriction enzyme analysis 
showed both of the cosmids to be identical (presumably originating from the same initial recombinant) and that they carried approximately $40 \mathrm{~kb}$ of human DNA.

\section{(c) Characterisation of t-PA genomic DNA}

The bacteriophage and cosmid clones were compared to the uncloned t-PA gene (in a total placental DNA preparation) by restriction enzyme analysis and Southern blotting using the nick-translated t-PA cDNA probe. $B g l \mathrm{II}$ digestion revealed the presence of a common single hybridising fragment of approx. $5.8 \mathrm{~kb}$ in length. Thus most, if not all, of the t-PA B chain is coded on this BglII fragment. We have mapped the cosmid with BamHI, ClaI, KpnI, PvuI and SalI (Fig. 1) and located the 5.8-kb BglII fragment. Further mapping experiments (not shown) enabled us to assign the orientation of the BglII fragment with respect to the cDNA clone and (using probe 1) to locate the $3^{\prime}$ end of the coding region (Fig. 1).

It was also of interest to determine whether any of the clones encoded the whole amino acid sequence of the t-PA protein. A second probe, with the sequence $5^{\prime}-\mathrm{d}$ (CCCTCTCTTCATTGCATCC)-3', corresponding to the $\mathrm{N}$-terminal region of the t-PA hydrophobic signal peptide (Pennica et al., 1983), was used to examine the genomic clones. None of the bacteriophage $\lambda$ clones hybridised to probe 2 indicating that they probably lacked the $5^{\prime}$ end of the gene. Probe 2 hybridised to a 3.9-kb Bam HI-KpnI fragment on the cosmid clone (Fig. 1). The fidelity of hybridisation was confirmed by subcloning and sequencing part of the 3.9-kb Bam HI-KpnI fragment (not shown). Location of probe 2 on this fragment indicales that the region containing the amino acid coding exons is between 17 and $21 \mathrm{~kb}$ long.

\section{(d) Expression of the t-PA cosmid clone}

The isolation of human t-PA bacteriophage (Pennica et al., 1983) and cosmid ( $\mathrm{Ny}$ et al., 1984) genomic clones has been described previously. In neither case was it demonstrated whether the whole t-PA genetic locus had been cloned. While it is possible to define the protein-coding areas of a gene by mapping and DNA sequencing, there are no definitive means of detecting regulatory elements (such as promoters) solely by structural analysis of cloned DNA. To demonstrate that the whole gene was present on our cosmid we examined its ability to direct the synthesis of human t-PA, using the dominant aminoglycosyl-3' -phosphotransferase selection marker present in the pTCF vector (Grosveld et al., 1982).

Mouse $\mathrm{L}$ cells were chosen as the host for the t-PA cosmid since we had found that these cells do not normally secrete plasminogen activator(s). Additionally, in the unlikely situation that manipulation of the $L$ cells might induce the expression of an endogenous murine plasminogen activator, we would be able to distinguish this from human t-PA on the basis of $M_{\mathrm{r}}$. Thus it is known that there are two major types of human plasminogen activator: u-PA $\left(M_{\mathrm{r}}\right.$ $53000)$ and t-PA $\left(M_{\mathrm{r}}\right.$ 63000-65000) (Heyneker
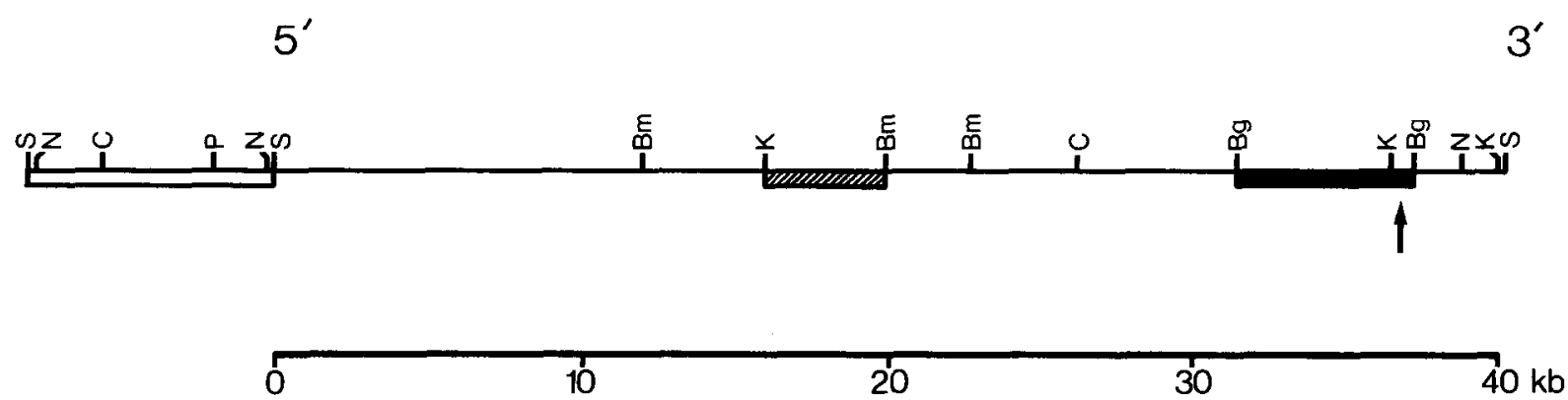

Fig. 1. Map of the t-PA cosmid clone. All ClaI, KpnI, $P v u \mathrm{I}$ and Sall sites are shown; only relevant BamHI and $B g l \mathrm{II}$ sites are shown. Black box represents the sole $B g l l l(5.8-\mathrm{kb})$ fragment hybridising to the t-PA cDNA probe; hatched box represents the $B a m H I-K p n I$ fragment hybridising to probe 2 (corresponding to the N-terminus of hydrophobic signal peptide); the arrow indicates the $B g l \mathrm{II}-\mathrm{KpnI}$ fragment hybridising to probe 1 ( $3^{\prime}$ end of protein-coding region); open box represents pTCF vector. The total length of inserted human DNA is $40 \mathrm{~kb} . \mathrm{Bg}=B g l \mathrm{II} ; \mathrm{Bm}=B a m \mathrm{HI} ; \mathrm{C}=C l a \mathrm{I} ; \mathrm{K}=K p n \mathrm{I} ; \mathrm{P}=P v u \mathrm{I} ; \mathrm{S}=S a l \mathrm{I}$. 
et al., 1982; Pennica et al., 1983). There is also a minor human t-PA component of approx. $M_{\mathrm{r}} 56000$ which is believed to be the product of limited proteolysis of the major species (Banyai et al., 1983). There are two analogous murine activators, one $\left(M_{\mathrm{r}}\right.$ $48000)$ immunologically rclated to u-PA and onc $\left(M_{\mathrm{r}}\right.$ 79000) immunologically related to t-PA (Marotti et al., 1982).

Cosmid DNA was introduced into $L$ cells as described in MATERIALS AND METHODS, section $\mathbf{h}$. $27 \mathrm{~L}$-cell clones were isolated and assayed for t-PA production: $55 \%$ of the clones secreted t-PA. The quantity produced by individual clones varied considerably; the highest yielding clone, TRL25, pro-

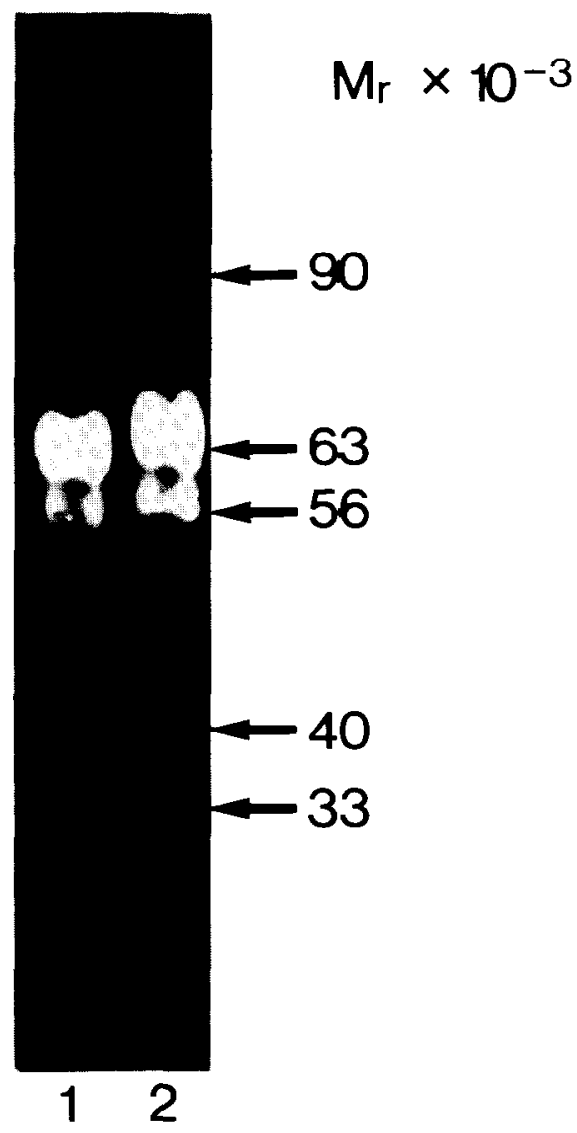

Fig. 2. SDS-polyacrylamide gel electrophoresis of t-PA. $20 \mu 1$ aliquots of Bowes melanoma cell-derived t-PA (lane 1) or recombinant mouse L cell (TRL25)-derived t-PA (lane 2) were electrophoresed in SDS-containing gels until the marker dye reached the bottom of the gel. Plasminogen activator activity, visualised as clear lysis areas against the Amido Black-stained background, was detected by fibrin zymography as described in MATERIALS AND METHODS, section $i$. The $M_{r}$ 's of the plasminogen activators were determined by comparing their mobility to known standards. duced approx. $70 \mathrm{ng} / \mathrm{ml}$ t-PA. Analysis of the purified protein by SDS-polyacrylamide gel electrophoresis and fibrin zymography showed that the fibrinolytically active species were of similar size to those produced by the human Bowes melanoma cell line (Fig. 2).

The identity of the recombinant protein was further confirmed as its fibrinolytic activity could be specifically quenched with anti-t-PA antibody whereas anti-u-PA antibody was without effect (not shown). Human t-PA and u-PA may also be distinguished on the basis of their dose-response curves in the fibrin plate assay (Rijken et al., 1979); we observed that the recombinant t-PA dose-response curve was similar to that of Bowes melanoma cell t-PA (not shown).

Expression of the human t-PA protein in mouse $L$ cells suggests that our cosmid encodes all of the t-PA protein molecule and in addition carries all the relevant structures (such as the promoter and poly(A) addition site) necessary for expression. The cosmid clone is thus likely to encompass the whole of the t-PA genetic locus.

The present study has also demonstrated the feasibility of expression of a cloned human t-PA gene in mammalian cell culture. While the yield of $t-P A$, even from our highest producing clone, is not at present optimal, there are now many methods of manipulating genes to increase expression (Rigby, 1982).

\section{ACKNOWLEDGEMENTS}

We would like to thank J.M. Dewdney, H. Ferres and $\mathbf{J}$. Green for their interest and encouragement of this work, P.W.J. Rigby and M.R.D. Scott for the pCD5 cloning system, M. Brightwell for HPLC purification of oligonucleotide probes, C. Brackley and P. Sefton for technical assistance, and A. Rogers for typing the manuscript.

\section{REFERENCES}

Banyai, L., Varadi, A. and Patthy, L.: Common evolutionary origin of the fibrin-binding structures of fibronectin and tissue-type plasminogen activator. FEBS Lett. 163 (1983) $37-41$. 
Benton, W.D. and Davis, R.W.: Screening $\lambda$ gt recombinant clones by hybridisation to single plaques in situ. Science 196 (1977) 180-182.

Dalbadie-MacFarland, G., Cohen, L.W., Riggs, A.D., Morin, C., Itakura, K. and Richards, J.H.: Oligonucleotide-directed mutagenesis as a general and powerful method for studies of protein function. Proc. Natl. Acad. Sci. USA 79 (1982) 6409-6413.

Edlund, T., Ny, T., Ranby, M., Heden, L., Palm, G., Holmgren, E. and Josephson, S.: Isolation of cDNA sequences coding for a part of human tissue plasminogen activator. Proc. Natl. Acad. Sci. USA 80 (1983) 349-352.

Gait, M.J., Matthes, H.W.D., Singh, M., Sproat, B.S. and Titmas, R.C.: Synthesis of oligodeoxyribonucleotides by a continuous flow, phosphotriester method on a kieselguhr/polyamide support, in Gassen, H.G. and Lang, A. (Eds.), Chemical and Enzymatic Synthesis of Gene Fragments-A Laboratory Manual, Verlag Chemie, Weinheim, 1982, pp. 1-42.

Granelli-Piperno, A. and Reich, E.: A study of proteases and protease-inhibitor complexes in biological fluids. J. Exp. Med. 148 (1978) 223-234.

Grosveld, F.G., Lund, T., Murray, E.J., Mellor, A.L., Dahl, H.H.M. and Flavell, R.A.: The construction of cosmid libraries which can be used to transform eukaryotic cells. Nucl. Acids Res. 10 (1982) 6715-6732.

Hanahan, D. and Meselson, M.: Plasmid screening at high colony density. Gene 10 (1980) 63-67.

Heyneker, H., Holmes, W., Rey, M., Pennica, D., Shepard, H.M., Seeburg, S., Hayflick, J., Ward, C., Vehar, G., Steffens, G., Guenzler, W., Oetting, F. and Flohe, L.: Functional expression of the human urokinase gene in Escherichia coli, in Ikeda, Y. and Beppu, T. (Eds.), Proceedings of the IVth International Symposium on Genetics of Industrial Microorganisms, Kodansha Ltd., Tokyo, 1982, pp. 214-221.

Hjelm, H., IJjelm, K. and Sjöquist, J.: Protein A from Staphylococcus aureus. Its isolation by affinity chromatography and its use as an immunosorbent for isolation of immunoglobulins. FEBS Lett. 28 (1972) 73-76.

Laemmli, U.K.: Cleavage of structural proteins during the assembly of the head of bacteriophage T4. Nature 227 (1970) $680-685$.

Lawn, R.M., Fritsch, E.F., Parker, R.C., Blake, G. and Maniatis, T.: The isolation and characterization of linked $\delta$ and $\beta$-globin genes from a cloned library of human DNA. Cell 15 (1978) $1157-1174$.

Legon, S., Glover, D.M., Hughes, J., Lowry, P.J., Rigby, P.W.J. and Watson, C.J.: The structure and expression of the preproenkephalin gene. Nucl. Acids Res. 10 (1982) 7905-7918.

Maniatis, T., Fritsch, E.F. and Sambrook, J. Molecular Cloning. A Laboratory Manual, Cold Spring Harbor Laboratory, Cold Spring Harbor, NY, 1982.
Marotti, K.R., Belin, D. and Strickland, S.: The production of distinct forms of plasminogen activator by mouse embryonic cells. Develop. Biol. 90 (1982) 154-159.

Maxam, A. and Gilbert, W.: Sequencing end-labelled DNA with base-specific chemical cleavages. Methods Enzymol. 65 (1980) 499-560.

Messing, J., Crea, R. and Seeburg, P.H.: A systcm for shotgun DNA sequencing. Nucl. Acids Res. 9 (1981) 309-321.

Ny, T., Bäckman, A., Elgh, F., Enquist, K., Fredriksson, C., Järvinen, S. and Lund, B.: Isolation and characterisation of the genomic region carrying the human tissue plasminogen activator gene. Haemostasis 14 (1984) 56.

Pennica, D., Holmes, W.E., Kohr, W.J., Harkins, R.N., Vehar, G.A., Ward, C.A., Bennett, W.F., Yelverton, E., Seeburg, P.H., Heyneker, H.L. and Goeddel, D.V.: Cloning and expression of human tissue-type plasminogen activator cDNA in E. coli. Nature 301 (1983) 214-221.

Rigby, P.W.J., Dieckmann, M., Rhodes, C. and Berg, P.: Labelling deoxyribonucleic acid to high specific activity in vitro by nick-translation with DNA polymerase 1 . J. Mol. Biol. 113 (1977) 237-251.

Rigby, P.W.J.: Expression of cloned genes in eukaryotic cells using vector systems derived from viral replicons, in Williamson, R. (Ed.), Genetic Engineering, Vol. 3. Academic Press, London, 1982, pp. 83-141.

Rijken, D.C., Wijngaards, G., Zaal-de Jong, M. and Welbergen, $\mathrm{J}$.: Purification and partial characterization of plasminogen activator from human uterine tissue. Biochim. Biophys. Acta 580 (1979) 140-153.

Rijken, D.C. and Collen, D.: Purification and characterization of the plasminogen activator secreted by human melanoma cells in culture. J. Biol. Chem. 256 (1981) 7035-7041.

Scott, M.R.D., Westphal, K. and Rigby, P.W.J.: Activation of mouse genes in transformed cells. Cell 34 (1983) 557-567.

Sinith, A.J.H.: DNA sequence analysis by primed synthesis. Methods in Enzymology 65 (1980) 560-580.

Southern, E.M.: Detection of specific sequences among DNA fragments separated by gel electrophoresis. J. Mol. Biol. 98 (1975) 503-517.

Thomas, P.S.: Ilybridization of denaturcd RNA and small DNA fragments transferred to nitrocellulose. Proc. Natl. Acad. Sci. USA 77 (1980) 5201-5205.

Van de Werf, F., Ludbrook, P.A., Bergmann, S.R., Tiefenbrunn, A.J., Fox, K.A.A., De Geest, H., Verstraete, M., Collen, D. and Sobel, B.E.: Coronary thrombolysis with tissue-type plasminogen activator in patients with evolving myocardial infarction. N. Engl. J. Med. 310 (1984) 609-613.

Weimar, W., Stibbe, J., Van Seyen, A.J., Billiau, A., De Somer, P. and Collen, D.: Specific lysis of an iliofemoral thrombus by administration of extrinsic (tissue-type) plasminogen activator. Lancet ii (1981) 1018-1020.

Communicated by K.F. Chater. 